\title{
Retrospective Analysis of Demographic, Epidemiologic, and Clinical Characteristics of Poisoning in Pediatric Intensive Care Unit
}

\section{Çocuk Yoğun Bakım Ünitesinde İzlenen Zehirlenme Olgularının Demografik, Epidemiyolojik ve Klinik Özelliklerinin Değerlendirilmesi}

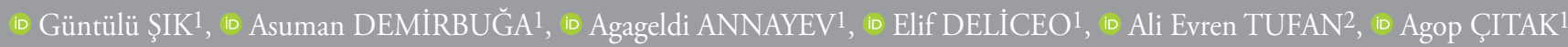

${ }^{1}$ Acıbadem Mehmet Ali Aydınlar University Faculty of Medicine, Department of Pediatric Intensive Care, İstanbul, Turkey

${ }^{2}$ Acıbadem Mehmet Ali Aydınlar Universty Faculty of Medicine Department of Child Adolescents and Mental Health Diseases, İstanbul,

Turkey

\begin{abstract}
Objective: Poisonings are significant causes of preventable morbidities and mortalities in pediatric patients hospitalized in pediatric intensive care units. In this study, we aimed to evaluate demographic and epidemiologic features, interventions, treatments, clinical course, and prognosis of patients hospitalized in pediatric intensive care unit for poisoning retrospectively.
\end{abstract}

Methods: The recordings of 172 patients admitted to the pediatric intensive care unit with acute poisoning between 2015 and 2019 were evaluated retrospectively.

Results: A total of 172 patients were admitted to our pediatric intensive care unit with the diagnosis of poisoning. Eighty-eight of them $(51.2 \%)$ were girl. The average age was $5.8 \pm 5.6$ years, and mean length of stay was 2.9 days. It was noted that $72.1 \%$ of patients with poisoning were accidental, whereas $27.9 \%$ of them were suicidal. Majority of suicidal patients were girls (89.5\%), and the mean age was $13.1 \pm 4.9$ years. However, only $36.2 \%$ of patients with accidental poisoning were girls and the mean age was $3.1 \pm 2.6$ years. Patients with poisoning were most commonly seen during spring. The most common cause of poisoning was drugs (76.7\%). Poisoning with multiple drugs were seen in 36 patients $(20.9 \%)$. Central nervous system drugs were the most common cause (32.7\%). Nausea-vomiting (17.4\%), altered mental status (12.7\%),

\section{ÖZ}

\begin{abstract}
Amaç: Zehirlenmeler çocuk yoğun bakım ünitelerine yatan hastalarda önlenebilir morbidite ve mortalitenin önemli bir kısmını oluşturmaktadır. Bu çalışmada, çocuk yoğun bakım ünitemizde zehirlenme nedeniyle tedavi edilen hastaların demografik ve epidemiyolojik özelliklerini, uygulanan tedavileri, klinik seyir ve prognozu geriye dönük olarak değerlendirmeyi amaçladık.
\end{abstract}

Yöntemler: Zehirlenme nedeniyle 2015-2019 tarihleri arasında çocuk yoğun bakım ünitemize yatırılan hastaların dosyaları geriye dönük olarak incelendi. Hastaların demografik özellikleri, uygulanan tedavi ve klinik bulgular kaydedildi.

Bulgular: Çocuk yoğun bakım ünitemize zehirlenme tanısıyla 172 hasta yatırıldı. Zehirlenmeler tüm hastaların \%8,7'sini oluşturdu. Hastaların \%51,2'si kız, \%48,8'i erkekti. Ortalama yaş 5,8 $\pm 5,6$ yıl, ortalama yatış süresi 2,9 gündü. Olguların \%27,9’u özkıyım amaçlı, \%72,1'si kaza sonucu meydana gelmişti. Özkıyım amacı ile zehirlenmelerde yaş ortalaması 13,1 $\pm 4,9$ yıldı ve hastaların \%89,6'sı kızdı. Kaza ile zehirlenmelerde ise yaş ortalaması 3,1 $\pm 2,6$ yıl iken, hastaların \%36,29'u kızdı. En sık başvuru ilkbahar mevsiminde ve nisan ayında oldu. Hastaların 132'sinde $(\% 76,7)$ zehirlenme nedeni ilaçlar iken, $40(\% 23,2)$ hastada ilaç dışı maddeler etkendi. Otuz altı hastada $(\% 20,9)$ çoklu etkenle zehirlenme vardı. En sık zehirlenme nedeni santral sinir sistemi ilaçlarıydı $(\% 32,7)$. İlaç
Address for Correspondence: Güntülü ŞIK, Acıbadem Mehmet Ali Aydınlar University Faculty of Medicine, Department of Pediatric Intensive Care, İstanbul, Turkey

E-mail: drguntulu@hotmail.com ORCID ID: orcid.org/0000-0002-4526-0485

Cite this article as: Şık G, Demirbuğa A, Annayev A, Deliceo E, Tufan AE, Çıtak A. Retrospective Analysis of Demographic, Epidemiologic, and Clinical Characteristics of Poisoning in Pediatric Intensive Care Unit. Bezmialem Science 2020;8(4):357-362.
Received: 21.11.2019

Accepted: 03.12.2019 
and abdominal pain $(7.5 \%)$ were the most common symptoms. Thirteen patients required invasive mechanical ventilation. Five patients were treated with hemodialysis and eight patients treated with plasma exchange.

Conclusion: Poisonings are important part of pediatric intensive care unit hospitalization. Accidental poisoning is common especially in children under five years of age. Taking preventive measures, educating parents about home accidents, storing medications in safe and locked places and keeping them out of reach of children can reduce the rate of accidental poisoning.

Keywords: Poisoning, pediatric intensive care, plasma exchange, continuous renal replacement treatment dışı etkenler arasında en sık neden mantar zehirlenmesiydi $(\% 3,7)$. En sık karşılaşılan klinik bulgular, bulantı-kusma $(\% 17,4)$, bilinç değişikliği $(\% 12,7)$ ve karın ağrısıydı $(\% 7,5)$. On üç hasta entübe edilerek izlendi. Beş hastaya hemodiyaliz, 8 hastaya plazma değişimi tedavisi yapıldı.

Sonuç: Zehirlenmeler çocuk yoğun bakım yatışlarının önemli bir kısmını oluşturmaktadır. Özellikle beş yaş altı çocuklarda kaza sonucu zehirlenmeler sık görülmektedir. Koruyucu önlemlerin alınması, ebeveynlerin ev kazaları konusunda eğitimi, ilaçların çocukların ulaşamayacağı, kilitli yerlerde ve emniyetli kapaklarla saklanması kaza ile gerçekleşen zehirlenme oranlarını azaltabilir.

Anahtar Sözcükler: Zehirlenmeler, çocuk yoğun bakımı, plazma değişimi, sürekli renal replasman tedavisi

\section{Introduction}

Poisoning is the emergence of some signs and symptoms as a result of taking a substance in high doses or by different routes. Childhood intoxications can progress with life-threatening symptoms, and early diagnosis and treatment are important in terms of morbidity and mortality.

All over the world, patients with intoxication occupy an important place among the patients admitted to the emergency department and hospitalized in intensive care unit. In the United States of America, more than 2 million people are admitted to the emergency department every year due to poisoning, and approximately $2 / 3$ of them are in the childhood age group (1). Of pediatric patients who are admitted due to poisoning, $80 \%$ are under the age of 5 (2). Among the childhood accidents in our country, intoxication ranks fourth after traffic accidents, falls and burns $(3,4)$.

Causes of poisoning may vary according to age group, sociocultural characteristics, education level of parents, country and regions. In our country, drug intoxication is seen most frequently. It occurs frequently as a result of accident between the ages of $1-5$, and in adolescents due to drug intake for suicide purposes (5).

The aim of this study was to determine the prevalence and demographic characteristics of patients with intoxication followed up in our pediatric intensive care unit, and to retrospectively examine the clinical course of the disease, the treatments applied and the duration of intensive care stay.

\section{Method}

The files of patients who were hospitalized in our pediatric intensive care unit due to poisoning between 2014 and 2019 were retrospectively analyzed. The study was approved by Mehmet Ali Aydınlar University Ethics committee (201911/18). Age, gender, poisoning agent, route of intoxication, cause of poisoning, month of admission, clinical findings, treatment and length of stay were recorded. Poisoning was divided into 2 groups as accident and suicide attempt.

\section{Statistical Analysis}

Statistical analyzes in this study were performed using the NCSS (Number Cruncher Statistical System) 2007 Statistical Software (Utah, USA) package program. In the evaluation of the data, besides descriptive statistical methods (mean, standard deviation, median, interquartil range), the Mann-Whitney U test was used in the comparison of binary groups of variables that did not show a normal distribution, and Fisher's Exact test and chi-square test were used in the comparison of qualitative data. The results were evaluated at the significance level of $\mathrm{p}<0.05$.

\section{Results}

One hundred and seventy two patients were admitted to our pediatric intensive care unit with the diagnosis of poisoning between January 2015 and May 2019. The number of patients followed up in intensive care unit between the same dates was 1955. Poisoning constituted $8.7 \%$ of all patients. Of the patients, $51.2 \%$ were girl and $48.8 \%$ were boy. The mean age was $5.8 \pm 5.6$ years (Table 1).

The reason for poisoning in 48 (27.9\%) patients was intake of drugs or non-drug substances for suicide purposes, the average age of these patients was $13.1 \pm 4.9$ years and $43(89.6 \%)$ were girl. The number of patients poisoned as a result of accident was $124(72 \%)$ and while the average age of these patients was $3.1 \pm 2.6$ years, $45(36.3 \%)$ of them were girl. Female gender was found to be significantly higher in intoxications due to suicide $(\mathrm{p}=0.0001)$. The most common admission month for all patients was April. When the evaluation was made according to the seasons, the frequency of poisoning for suicide in the spring was significantly higher than the frequency of poisoning due to accident $(\mathrm{p}=0.006)$ (Table 1$)$.

While the cause of poisoning was drugs in 132 (76.7\%) of the patients, non-drug substances were the cause in $40(23.3 \%)$ patients. Intake of 214 drugs was detected in 175 patients. Thirtysix patients $(20.9 \%)$ had multiple agent intoxication. Thirty patients took 2 different drugs while 6 patients took 3 different drugs. Multiple drug intake was higher in patients of suicidal poisoning $(\mathrm{p}=0.0001)$. Among the drugs, the most common 
Table 1. Patient characteristics, age, gender and seasonal distribution

\begin{tabular}{|c|c|c|c|c|c|c|c|c|}
\hline \multirow[t]{2}{*}{$n$} & & \multicolumn{2}{|c|}{$\begin{array}{l}\text { Whole group } \\
n=172\end{array}$} & \multicolumn{2}{|c|}{$\begin{array}{l}\text { Accident group } \\
n=124\end{array}$} & \multicolumn{2}{|c|}{$\begin{array}{l}\text { Suicide group } \\
\mathrm{n}=48\end{array}$} & \multirow{2}{*}{$\mathrm{p}$} \\
\hline & & $\%$ & $\mathrm{n}$ & $\%$ & $\mathrm{n}$ & $\%$ & & \\
\hline \multirow{3}{*}{ Gender } & Boy & 84 & $48.8 \%$ & 79 & $63.7 \%$ & 5 & $10.4 \%$ & \\
\hline & Girl & 88 & $51.2 \%$ & 45 & $36.3 \%$ & 43 & $89.6 \%$ & 0.0001 \\
\hline & Spring & 54 & $31.4 \%$ & 31 & $25 \%$ & 23 & $47.9 \%$ & $0.006+$ \\
\hline \multirow{3}{*}{ Event season } & Summer & 42 & $24.4 \%$ & 33 & $26.6 \%$ & 9 & $18.7 \%$ & $0.379+$ \\
\hline & Autumn & 38 & $22.1 \%$ & 29 & $23.4 \%$ & 9 & $18.7 \%$ & $0.651+$ \\
\hline & Winter & 38 & $22.1 \%$ & 31 & $25 \%$ & 7 & $14.6 \%$ & $0.203+$ \\
\hline \multirow{2}{*}{ Single/Multiple drugs } & Multiple & 36 & $20.9 \%$ & 14 & $11.3 \%$ & 22 & $45.8 \%$ & \\
\hline & Single & 136 & $79.1 \%$ & 110 & $88.7 \%$ & 26 & $54.2 \%$ & $0.0001+$ \\
\hline Age (years) & Mean \pm SD & \multicolumn{2}{|l|}{$5.8 \pm 5.6$} & \multicolumn{2}{|c|}{$3.1 \pm 2.6$} & \multicolumn{2}{|c|}{$13.1 \pm 4.9$} & $0.0001 *$ \\
\hline Stay at intensive care unit (days) & Mean \pm SD & \multicolumn{2}{|l|}{$2.9 \pm 2.7$} & \multicolumn{2}{|c|}{$2.7 \pm 2.8$} & \multicolumn{2}{|c|}{$3.6 \pm 2.5$} & $0.0001 *$ \\
\hline
\end{tabular}

cause of intoxication was central nervous system drugs $(32.7 \%)$ and antidepressants were in the first place (14.9\%) among them. When all drugs were evaluated, analgesic-antipyretic drugs (13.5\%) were the second and cardiovascular system drugs $(10.7 \%)$ were the third. Among the non-drug factors, the most common cause was mushroom poisoning (3.7\%) (Table 2$)$.

Ninety eight different clinical signs were detected in 78 patients. The most common symptoms in patients with clinical findings were nausea-vomiting $(17.4 \%)$, altered consciousness $(12.7 \%)$ and abdominal pain (7.5\%). Hypotension (4.6\%), respiratory distress (4\%), diarrhea (4\%), tachycardia (4\%) and agitation $(2.3 \%)$ were other findings (Table 3$)$.

Thirteen patients were intubated (4 amitriptyline, 3 carbamazepine, 2 colchicine, 1 valproic acid, 1 metformin, 1 verapamil, 1 mushroom poisoning). Of these patients, $76.9 \%$ poisoned for suicide purposes. Continuous venovenous hemodialysis (2 carbamazapine, 1 metformin, 1 colchicine, and 1 valproic acid intoxication) was administered in 5 patients, and plasma exchange (3 mushroom, 3 colchicine, 2 carbamazepine poisoning) treatment was performed in 8 patients (Table 4).

Average length of stay in intensive care unit was 2.9 \pm 2.7 days. The mean hospitalization period (3.6 \pm 2.5 days) in intoxications for suicide was found to be significantly higher than in intoxications by accident $(2.7 \pm 2.8$ days $)(p=0.0001)$. No patient died due to poisoning, all patients were discharged without any sequelae. No complications were observed due to the medical and extracorporeal treatment methods applied. All patients who presented with suicidal poisoning at discharge were evaluated by a child psychiatrist.

\section{Discussion}

Poisoning is one of the major causes of preventable mortality and morbidity in children. All over the world, patients with poisoning increase over the years $(6,7,8)$. In a study performed in Turkey in 5,077 children with poisoning, $0.9 \%$ of patients admitted to the emergency were identified as patients with poisoning (7). According to the report of the National Poison Control Center childhood poisonings constitutes $60 \%$ of all poisonings in Turkey. While accidents are the most common cause of intoxication in children under 4 years of age, in the childhood age group, drug intake for suicidal purposes is more common above the age of 15 (9).

In a study conducted in India, 9.3\% of patients admitted to intensive care unit were patients with poisoning (10), while in a study conducted in Turkey, this rate was $10.7 \%$ (11). In a study in which Toptaş et al. (12) evaluated patients with poisoning in intensive care unit over 6 years, it was found that 59 patients were admitted to intensive care unit with a diagnosis of poisoning and these patients accounted for $1.4 \%$ of the total intensive care hospitalization. Although admission rates differ, in our study, the total number of patients admitted to our children's intensive care unit over a 4-year period was 1955, and we found that patients with acute poisoning accounted for $8.7 \%$ of these patients.

Accidental poisoning is mostly seen in boys aged 1-5 years (13). Increasing physical activity and learning curiosity, families not being educated about poisoning, and keeping medicines and non-pharmaceutical substances in easy reach of the child can be listed among the reasons for this. In our study, the average age of intoxication due to accidents was 3.1 years and $63.7 \%$ of the patients were boy. Poisoning for suicide purposes is mostly seen in the adolescent age group and girls $(11,14)$. Similar to the studies conducted, we found that $89.6 \%$ of the patients with poisoning with suicidal purposes were girls at adolescent age. We think that the reason for this is that in our society, the responsibility and value attributed to girls in the family are different than that of boys, the expectation for housework and home dependency is kept high, and therefore they are more exposed to domestic problems. 
Table 2. Prevalence of drugs and non-drug substances that cause intoxication

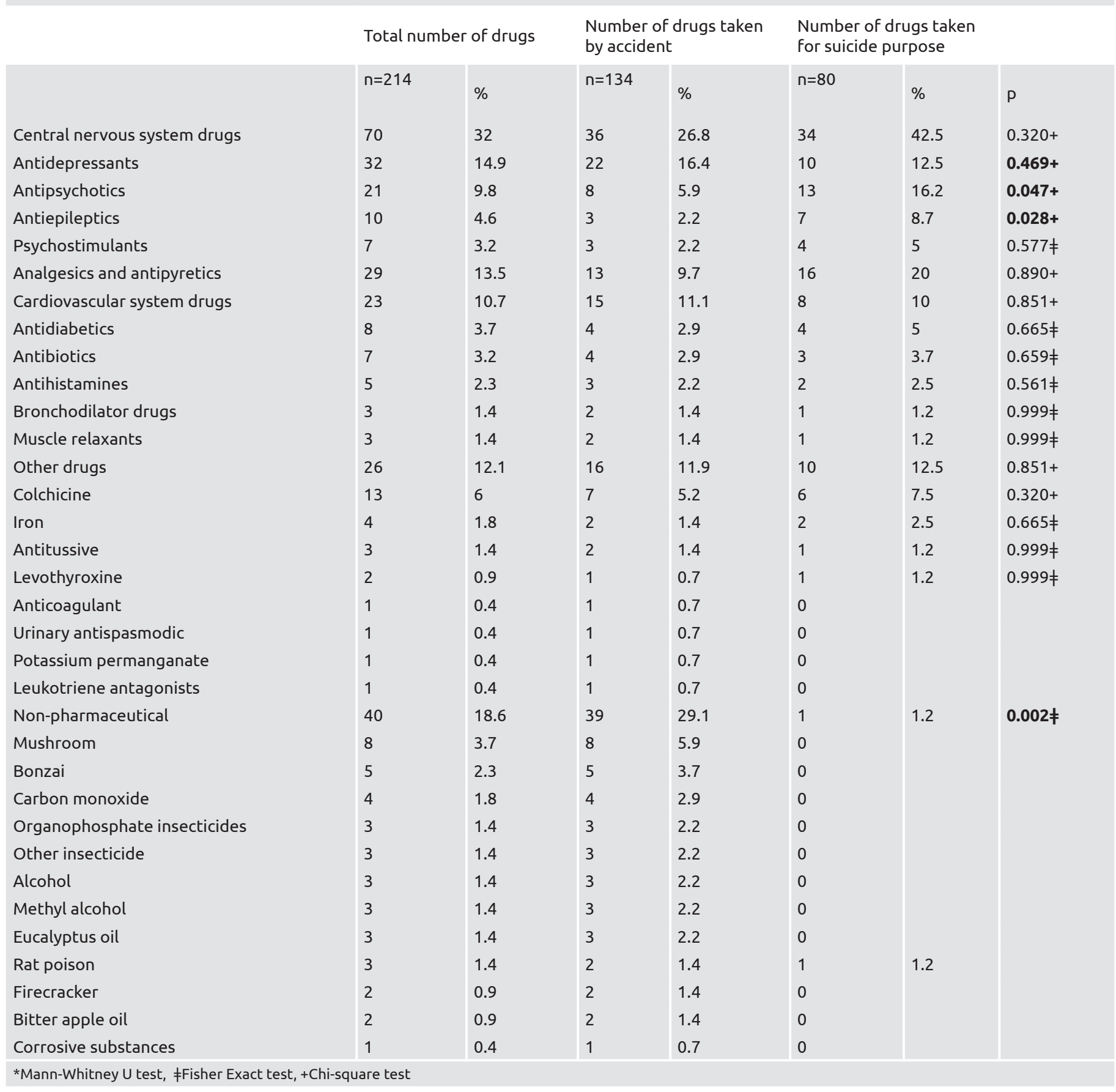

Table 3. Clinical findings of the patients

\begin{tabular}{|l|l|l}
\hline Nausea and vomiting & $\mathrm{n}$ & $\%$ \\
\hline Change in consciousness & 30 & 17.4 \\
Abdominal pain & 22 & 12.7 \\
Hypotension & 13 & 7.5 \\
Respiratory distress & 8 & 4.6 \\
Diarrhea & 7 & 4 \\
Tachycardia & 7 & 4 \\
Agitation & 7 & 4 \\
\hline
\end{tabular}

Table 4. Procedures applied to patients

\begin{tabular}{|l|l|l|}
\hline Gastric lavage & n & $\%$ \\
\hline Activated carbon & 44 & 25.5 \\
\hline Mechanical ventilation & 30 & 17.4 \\
\hline Plasma exchange & 13 & 7.5 \\
\hline Continuous renal replacement therapy & 8 & 4.6 \\
\hline
\end{tabular}


Özdemir et al. showed in their study that $64.4 \%$ of intoxications occurred with drugs in patients who were followed up in pediatric intensive care unit (15). This rate was $60.2 \%$ in the study by Tekerek et al. (16). Similarly, in our study, the cause of intoxication in $76.7 \%$ of the patients was drugs.

Many studies have shown that central nervous system drugs are the most common cause of intoxication in children (17). Studies conducted in our country show similarities with the whole world $(16,18)$. Central nervous system drugs were the most common cause of drug intoxication in our patients. Among these, the most common group was antidepressant drugs. Similar to our study, analgesic drugs are frequently in the second place in the studies. In our country, easy access to antidepressants and analgesic drugs, the availability of many drugs in this group without a prescription, frequent use by adults, being in every home, being kept in accessible places for children, and not having locked covers cause frequent poisoning with these drugs.

In the study conducted by Lijun et al. (19) in China, CO poisoning, food poisoning and pesticides took the first place in non-drug poisoning. In studies conducted in our country, corrosive substances are frequently encountered among non-drug intoxication agents (16). In the study conducted by Ayoğlu et al. (20), medical drugs were the leading agents in children brought to the emergency room due to poisoning, followed by corrosive substances, organophosphate insectists, mushrooms, alcohol and rat poison, respectively. In another study conducted by Akbaba et al. (21), organophosphate pesticides were the most common cause of non-drug intoxication. In our study, mushroom intoxications took the first place among non-drug intoxications. Acute liver failure may develop in mushroom poisoning and it is recommended that risky patients be followed up in liver transplant centers. Since our hospital is a liver transplant center, these patients are admitted to our unit from various centers. For this reason, we see mushroom poisoning more frequently than other studies.

In our study, we found clinical findings in $45.3 \%$ of patients with intoxication. Of the patients, $17.4 \%$ had nausea-vomiting, $12.7 \%$ change in consciousness, and $7.5 \%$ abdominal pain. In the study conducted by Ağın et al. (22), 59\% of the patients were symptomatic and the most common finding was nausea and vomiting (18\%). Tekerek et al. (16) detected change in consciousness in $53 \%$ of the patients who were followed up in the pediatric intensive care unit due to poisoning. Oner et al. (23) found nausea-vomiting in $22.9 \%$ and restlessness and arrhythmia in $19.4 \%$ of patients with intoxication. In other studies, it has been reported that more than half of the patients are asymptomatic, but clinical findings and altered consciousness can be observed $(9,24,25)$. Kendirci et al. (26) found nausea in 73 patients $(28.6 \%)$ and abdominal pain in 52 patients $(20.4 \%)$ in their study. In other studies, Binay et al. (25) found vomiting (30.2\%), Sümer et al. (17) nausea-vomiting (14.1\%) and change in consciousness $(13.3 \%)$ as the most common findings among all intoxications.

The main treatment in poisoning is the general approach to the emergency patient and providing basic and advanced life support.
In addition, preventing and reducing the absorption of the active substance that causes intoxication, administration of systemic antidotes, accelerating the excretion of the active substance from the body, and symptom-oriented treatment should be performed (27). The rate of activated charcoal administration in pediatric patients admitted to the emergency department for poisoning varies between 50-55\%. The most common treatments we applied were gastric lavage (25.5\%) and activated charcoal administration (17.4\%). Although the rates of intubation due to poisoning vary in studies, 13 patients $(7.5 \%)$ in our study were intubated and followed up on a mechanical ventilator.

In our country, mortality rates due to poisoning in pediatric patients vary between $0-5 \%(28,29)$. Tekerek et al. (16) showed in their study that the mortality rate was $5.4 \%$ in patients who were followed in the pediatric intensive care unit due to poisoning and found that $50 \%$ of the patients who died had ingested corrosive substance and $20 \%$ of them took colchicine. In another study in our country, the mortality rate was $0.4 \%$ (17). While the death rate due to poisoning was $0.4 \%$ in England, this rate was found to be $8.9 \%$ in India $(30,31)$. In our study, no patient died.

\section{Conclusion}

Poisoning constitutes an important part of pediatric intensive care unit admissions and is one of the preventable causes of mortality and morbidity in childhood. Accidental drug intake constitutes the majority of intoxications. Since accidental poisoning is common especially in children under the age of five, it is very important to implement protective measures. Educating families on home accidents, raising awareness, safe caps for medicines, and reducing over-the-counter medications can reduce accidental poisoning rates.

\section{Ethic}

Ethics Committee Approval: Mehmet Ali Aydınlar University Ethics Committee decision number: 2019-11/18.

Informed Consent: Informed consent was not obtained as the study design was retrospective.

Peer-review: Externally peer reviewed.

\section{Authorship Contributions}

Concept: A.Ç., G.Ş. Design: G.Ş., A.Ç. Data Collection or Processing: G.Ş., A.Ç., Analysis or Interpretation: G.Ş., A.Ç., Literature Search: G.Ş., Writing: G.Ş.

Conflict of Interest: No conflict of interest was declared by the authors.

Financial Disclosure: No financial support was declared by the authors.

\section{References}

1. Bronstein AC, Spyker DA, Cantilena LR Jr, Rumack BH, Dart RC. 2011 Annual report of the American Association of Poison Control Centers' National Poison Data System (NPDS): 29th Annual Report. Clin Toxicol (Phila) 2012;50:911-1164. 
2. Jepsen F, Ryan M. Poisoning in children. Curr Pediatr 2005;15:5638.

3. Yavuz S, Aydın S. Zehirlenme olgularının profili. Toksikol Derg 2003;1:47-52.

4. Sarıkayalar F. Çocuklarda zehirlenmeler. Katkı Pediatri Dergisi 2001;22:377-95.

5. Sahin S, Carman KB, Dinleyici EC. Acute poisoning in children; data of a pediatric emergency unit. Iran J Pediatr 2011;21:479-84.

6. Nalliah RP, Anderson IM, Lee MK, Rampa S, Allareddy V, Allareddy V. Children in the United States make closeto 200,000 emergency department visits due to poisoning each year. Pediatr Emerg Care 2014;30:453-7.

7. Çıtak A, Yılmaz HL, Tunçok Y, editors. Çocuklarda Zehirlenme: Tanı ve Tedavi. İstanbul: Medikal Yayıncılık; 2010.

8. Litovitz TL, Klein-Schwartz W, Caravati EM, Youniss J, Crouch B, Lee S, et al. 1998 annual report of the American Association of Poison Control Centers Toxic Exposure Surveillance System. Am J Emerg Med 1999;17:435-87.

9. Özcan N, İkincioğulları D. Ulusal zehir danışma merkezi 2008 yılı çalışma raporu özeti. Türk Hij Den Biyol Derg 2009;66:29-58.

10. Singh O, Javeri Y, Juneja D, Gupta M, Singh G, Dang R. Profile and outcome of patients with acute toxicity admitted in intensive care unit: Experiences from a major corporate hospital in urban India. Indian J Anaesth 2011;55:370-4.

11. Özayar E, Değerli S, Güleç H, Şahin Ş, Dereli N. Yoğun bakıma kabul edilen zehirlenme olgularının retrospektif Analizi. Yoğun Bakım Derg 2011;3:59-62.

12. Toptaş M, Akkoç İ, Kaya R, Uzman S, Gül YG, Yılmaz Y, et al. Akut zehirlenme hastalarının profili ve prognoza etkili faktörler: Yoğun bakımda geriye dönük bir analiz. Med Bull Haseki 2014:52;29-33.

13. Biçer S, Sezer S, Çetindağ F, Kesikminare M, Tombulca N, Aydoğan G, et al. Çocuk Acil Kliniği 2005 Yılı Akut Zehirlenme Olgularının Değerlendirilmesi. Marmara Med J 2007;20:12-20.

14. Gündüz A, Kesen J, Topbaş M, Narcı H, Yandı M. Analysis of suicidal poisoning patients presented to emergency department. TAF Prev Med Bull 2004;3:234-42.

15. Ozdemir R, Bayrakci B, Tekşam O, Yalçin B, Kale G. Thirty-threeyear experience on childhood poisoning. Turk J Pediatr 2012;54:2519.

16. Tekerek NÜ, Dursun A, Akyıldız BN. Çocuk yoğun bakım ünitesinde takip edilen zehirlenme olgularının geriye dönük değerlendirilmesi. J Pediatr Emerg Intensive Care Med 2016;3:21-6.

17. Sümer V, Güler E, Karanfil R, Dalkıran T, Gürsoy H, Garipardıç $\mathrm{M}$, et al. Çocuk acil servisine başvuran zehirlenme olgularının geriye dönük olarak değerlendirilmesi. Türk Ped Arş 2011;46:234-40.
18. Güngörer V, Yıldırım NK. Yeni açılan ikinci düzey çocuk yoğun bakım birimimizde yatan zehirlenme olgularının değerlendirilmesi. Turkish Arch Pediatr 2016;51:35-9.

19. Wang L, Wu Y, Yin P, Cheng P, Liu Y, Schwebel DC, et al. Poisoning deaths in China, 2006-2016. Bull World Health Organ 2018;96:31426.

20. Ayoğlu NF, Ayoğlu H, Macit Kaptan YM, Özkoçak Turan IÖ. A Retrospective Analysis of Cases with Acute Poisoning in Zonguldak, Turkey. TARD 2009;37:240-8.

21. Akbaba M, Nazlican E, Demirhindi H, Sütoluk Z, Gökel Y. Etiological and demographical characteristics of acute adult poisoning in Adana, Turkey. Hum Exp Toxicol 2007;26:401-6.

22. Ağın H, Çalkavur Ş, Olukman Ö, Ural R ve Bak M. Çocukluk çağında zehirlenmeler: son 2 yıldaki olguların değerlendirilmesi. Turkiye Klinikleri J Pediatr 2002;11:186-93.

23. Öner N, Vatansever Ü, Turan Ç, Okutan Ö, Şimşek A, Duran R, et al. Çocuklarda sık görülen zehirlenmelerden biri: Amitriptilin zehirlenmesi. Turkiye Klinikleri J Pediatr 2004;13:123-8.

24. Kahveci M, Çeltik C, Karasalihoğlu S, Acunaş B. Bir üniversite hastanesi acil servisine başvuran çocukluk çağı zehirlenmelerinin değerlendirilmesi. STED 2004;13:1-21.

25. Binay Ç, Tunca Şahin G, Biçer S, Gemici H, Şahin S, Bahar S, et al. Çocuk acil ünitesi 2006 yılı zehirlenme vakalarının değerlendirilmesi. JAEM 2010;9:31-40.

26. Peltek Kendirci HN, Yağlı Çolakoğlu E, Hızlı Ş, Koçak M, Saylam E, Polat E, et al. Hastanemiz çocuk acil servisine başvuran zehirlenme olgularının değerlendirilmesi. Türkiye Çocuk Hast Derg 2011;5:2935.

27. Kondolot M, Akyıldız B, Görözen F, Kurtoğlu S, Patıroğlu T. Çocuk acil servisine getirilen zehirlenme olgularının değerlendirilmesi. Cocuk Sagligi ve Hastaliklari Derg 2009;52:68-74.

28. Yorulmaz A, Akbulut H, Yahya İ, Aktaş R, Emiroğlu HH, Peru H. Retrospective Evaluation of Patients Admitted to the Pediatric Emergency Department with Intoxication. Turkish J Pediatr Emerg Intensive Care Med 2017;4:96-103.

29. Soyucen E, Aktan Y, Saral E, Akgün N, Numanoğlu AU. Retrospective analysis of childhood poisoning in sakarya region. Cocuk Sagligi ve Hastaliklari Derg 2006;49:301-6.

30. Even KM, Armsby CC, Bateman ST. Poisonings requiring admission to the pediatric intensive care unit: A 5-year review. Clin Toxicol (Phila) 2014;52:519-24.

31. Jayashree M, Singhi S. Changing trends and predictors of outcome in patients with acute poisoning admitted to the intensive care. J Trop Pediatr 2011;57:340-6. 